Research review paper

\title{
Bioactive phenolic compounds: Production and extraction by solid-state fermentation. A review
}

\author{
Silvia Martins ${ }^{\text {a }}$, Solange I. Mussatto a,*, Guillermo Martínez-Avila ${ }^{\text {b }}$, Julio Montañez-Saenz ${ }^{\text {c }}$, \\ Cristóbal N. Aguilar ${ }^{\mathrm{b}}$, Jose A. Teixeira ${ }^{\mathrm{a}}$ \\ a Institute for Biotechnology and Bioengineering (IBB), Centre of Biological Engineering, University of Minho, Campus Gualtar, 4710-057, Braga, Portugal \\ ${ }^{b}$ Food Research Department, School of Chemistry, Autonomous University of Coahuila, Blvd. Venustiano Carranza S/N Col. República Oriente, 25280, Saltillo, Coahuila, Mexico \\ ' Department of Chemical Engineering, School of Chemistry, Autonomous University of Coahuila, Blvd. Venustiano Carranza S/N Col. República Oriente, 25280, Saltillo, Coahuila, Mexico
}

\section{A R T I C L E I N F O}

\section{Article history:}

Received 27 July 2010

Received in revised form 20 January 2011

Accepted 21 January 2011

Available online 1 February 2011

\section{Keywords:}

Solid-state fermentation

Agro-industrial residues

Plants

Bioactive compounds

Phenolic compounds

\begin{abstract}
A B S T R A C T
Interest in the development of bioprocesses for the production or extraction of bioactive compounds from natural sources has increased in recent years due to the potential applications of these compounds in food, chemical, and pharmaceutical industries. In this context, solid-state fermentation (SSF) has received great attention because this bioprocess has potential to successfully convert inexpensive agro-industrial residues, as well as plants, in a great variety of valuable compounds, including bioactive phenolic compounds. The aim of this review, after presenting general aspects about bioactive compounds and SSF systems, is to focus on the production and extraction of bioactive phenolic compounds from natural sources by SSF. The characteristics of SSF systems and variables that affect the product formation by this process, as well as the variety of substrates and microorganisms that can be used in SSF for the production of bioactive phenolic compounds are reviewed and discussed.
\end{abstract}

(c) 2011 Elsevier Inc. All rights reserved.

\section{Contents}

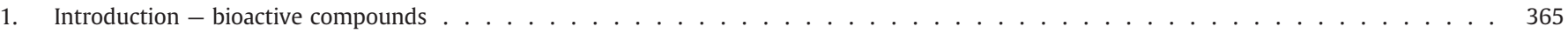

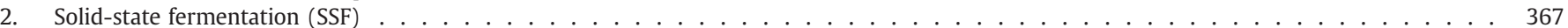

3. Uses of SSF for bioactive phenolic compounds production . . . . . . . . . . . . . . . . . . . . . . . . . . . . . . 369

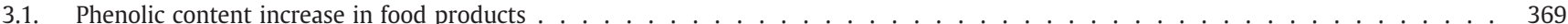

3.2. Production and extraction of bioactive phenolic compounds from agro-industrial residues . . . . . . . . . . . . . . . . . 369

3.3. Production and extraction of bioactive phenolic compounds from plants . . . . . . . . . . . . . . . . . . . . . . . . . 370

4. Concluding remarks and future perspective . . . . . . . . . . . . . . . . . . . . . . . . . . . . . 371

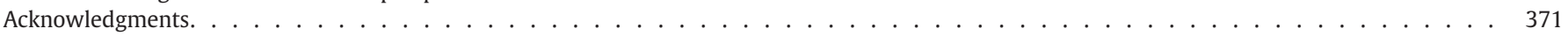

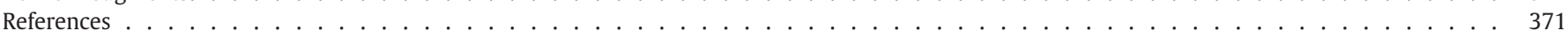

\section{Introduction - bioactive compounds}

Bioactive compounds are extra nutritional constituents that naturally occur in small quantities in plant and food products (Kris-Etherton et al., 2002). Most common bioactive compounds include secondary metabolites such as antibiotics, mycotoxins, alkaloids, food grade pigments, plant growth factors, and phenolic compounds (Hölker et al., 2004; Kris-Etherton et al., 2002; Nigam, 2009). Phenolic compounds comprise flavonoids, phenolic acids, and tannins, among

\footnotetext{
* Corresponding author. Tel.: + 351253604 424; fax: + 351253604429.

E-mail addresses: solange@deb.uminho.pt, solangemussatto@hotmail.com (S.I. Mussatto)
}

others. Flavonoids constitute the largest group of plant phenolics, accounting for over half of the eight thousand naturally occurring phenolic compounds (Harborne et al., 1999). Variations in substitution patterns to ring $C$ in the structure of these compounds result in the major flavonoid classes, i.e., flavonols, flavones, flavanones, flavanols, isoflavones, and anthocyanidins. Fig. 1 shows examples of the most common naturally occurring flavonoids. Similarly to the flavonoids, phenolic acids constitute also an important class of phenolic compounds with bioactive functions, usually found in plant and food products. Phenolic acids can be divided in two subgroups according to their structure: the hydroxybenzoic and the hydroxycinnamic acids (Fig. 2). The most commonly found hydroxybenzoic acids include gallic, $p$ hydroxybenzoic, protocatechuic, vanillic and syringic acids, while 
366

S. Martins et al. / Biotechnology Advances 29 (2011) 365-373

ISOFLAVONES<smiles>O=c1c(-c2ccc(O)cc2)coc2cc(O)ccc12</smiles>

Daidzein

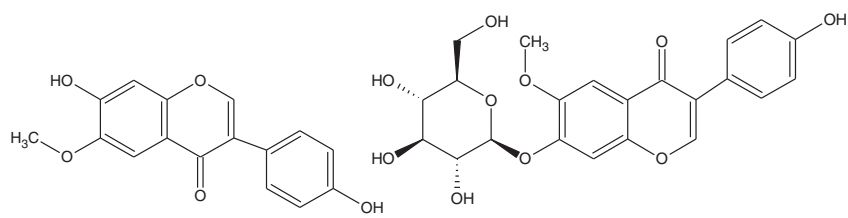

Glycitein

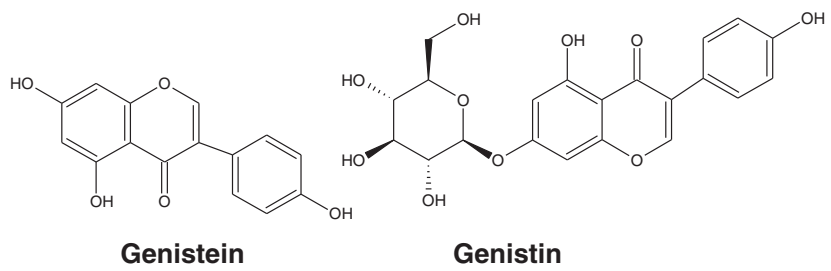

FLAVONES
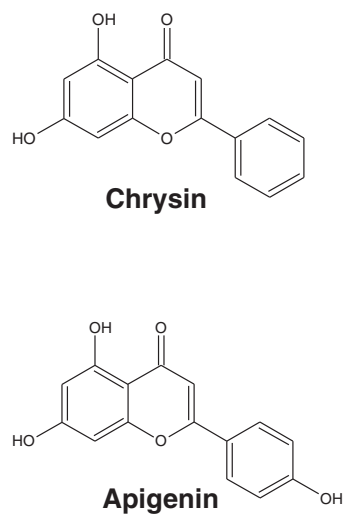

FLAVANONES

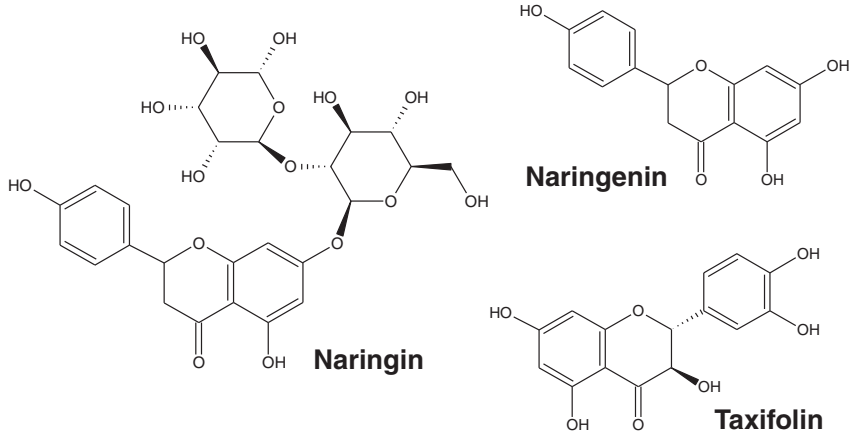

FLAVANOLS

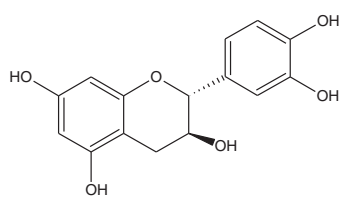

Catechin

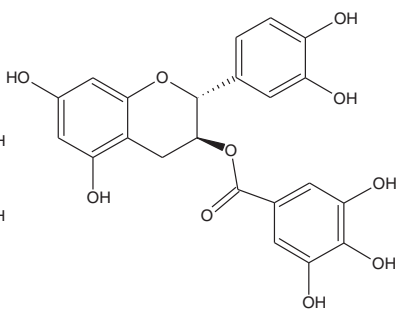

Catechin gallate<smiles>Oc1cc(O)c2c(c1)O[C@H](c1cc(O)c(O)c(O)c1)[C@H](O)C2</smiles><smiles>Oc1cc(O)c2c(c1)O[C@H](c1ccc(O)c(O)c1)[C@H](O)C2</smiles>

Epigallocatechin

Epicatechin<smiles>O=C(O[C@H]1Cc2c(O)cc(O)cc2O[C@H]1c1ccc(O)c(O)c1)c1cc(O)c(O)c(O)c1</smiles><smiles>O=C(O[C@@H]1Cc2c(O)cc(O)cc2O[C@H]1c1cc(O)c(O)c(O)c1)c1cc(O)c(O)c(O)c1</smiles>

Epicatechin gallate

Epigallocatechin gallate

FLAVONOLS

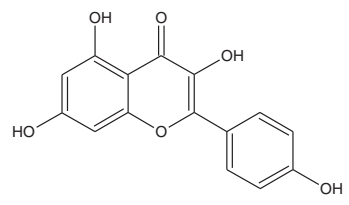

Kaempferol<smiles>CCCCOC(C)=O</smiles><smiles>CC(C)(C)CCCCCCCO</smiles>

ANTHOCYANIDINS
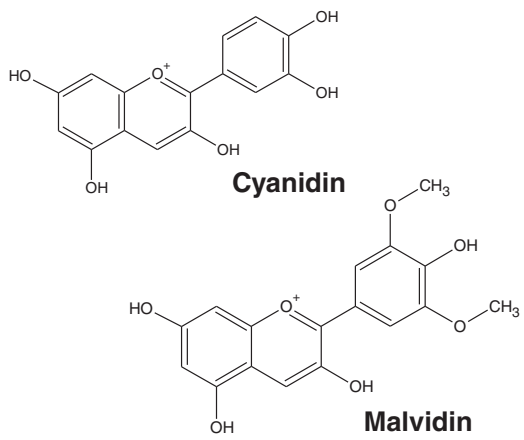

Fig. 1. Examples of naturally occurring flavonoids. 


\section{HYDROXYBENZOIC ACIDS}<smiles>O=C(O)c1cc(O)c(O)c(O)c1</smiles>

Gallic acid<smiles>COc1cc(C(=O)O)ccc1O</smiles><smiles>O=c1oc2c(O)c(O)cc3c(=O)oc4c(O)c(O)cc1c4c23</smiles>

Ellagic acid<smiles>O=C(O)c1cc(O)ccc1O</smiles>

Gentisic acid<smiles>O=C(O)c1ccc(O)c(O)c1</smiles>

Protocatechuic acid<smiles>O=C(O)c1ccc(O)cc1</smiles>

\section{p-Hydroxybenzoic acid}<smiles>COc1cc(C(=O)O)cc(OC)c1O</smiles>

Syringic acid<smiles>O=C(O)c1ccccc1O</smiles>

Salicylic acid

\section{HYDROXYCINNAMIC ACIDS}<smiles>COc1cc(/C=C/C(=O)O)ccc1O</smiles><smiles>O=C(O)/C=C/c1ccc(O)c(O)c1</smiles>

Caffeic acid<smiles>O=C(O)/C=C/c1ccc(O)cc1</smiles><smiles>COC1=CC(/C=C/C(=O)O)CC(OC)=C1O</smiles><smiles>O=C(O)/C=C/c1ccccc1</smiles>

Cinnamic acid

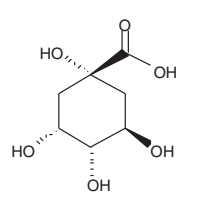

Quinic acid

Fig. 2. Examples of naturally occurring phenolic acids.

among the hydroxycinnamic acids, caffeic, ferulic, $p$-coumaric and sinapic acids can be pointed out (Bravo, 1998).

In the last few years, great attention has been paid to the bioactive compounds due to their ability to promote benefits for human health, such as the reduction in the incidence of some degenerative diseases like cancer and diabetes (Conforti et al., 2009; Kim et al., 2009), reduction in risk factors of cardiovascular diseases (Jiménez et al., 2008; Kris-Etherton et al., 2002), antioxidant, anti-mutagenic, anti-allergenic, anti-inflammatory, and anti-microbial effects (Balasundram et al. 2006; Ham et al. 2009; Parvathy et al. 2009), among others. Due to these countless beneficial characteristics for human health, researches have been intensified aiming to find fruits, vegetables, plants, agricultural and agro-industrial residues as sources of bioactive phenolic compounds.

Usually, bioactive compounds are recovered from natural sources by solid-liquid extraction employing organic solvents in heat-reflux systems (Martins et al., 2010; Wang and Weller, 2006). However, other techniques have been recently proposed to obtain these compounds including the use of supercritical fluids, high pressure processes, microwave-assisted extraction and ultrasound-assisted extraction (Cortazar et al. 2005; Markom et al. 2007; Wang and Weller, 2006). Extraction/production of bioactive compounds by fermentation is also an interesting alternative that merits attention, since it is able to provide high quality and high activity extracts while precluding any toxicity associated to the organic solvents. In this process, bioactive compounds are obtained as secondary metabolites produced by microorganisms after the microbial growth is completed (Nigam, 2009). Studies on liquid culture show that the production of these compounds starts when growth is limited by the exhaustion of one key nutrient: carbon, nitrogen or phosphate source (Barrios-González et al. 2005).

The purpose of this article is to provide an overview of the bioactive phenolic compounds extraction and production by fermen- tation, more specifically by the solid-state fermentation technique. The current status of this technology, the microorganisms, substrates and cultivation conditions affecting the phenolic compounds formation are summarized and discussed.

\section{Solid-state fermentation (SSF)}

Fermentation processes may be divided into two systems: submerged fermentation (SmF), which is based on the microorganisms cultivation in a liquid medium containing nutrients, and solidstate fermentation (SSF), which consists of the microbial growth and product formation on solid particles in the absence (or near absence) of water; however, substrate contains the sufficient moisture to allow the microorganism growth and metabolism (Pandey, 2003). In recent years, SSF has received more interest from researchers since several studies have demonstrated that this process may lead to higher yields and productivities or better product characteristics than SmF. In addition, due to the utilization of low cost agricultural and agroindustrial residues as substrates, capital and operating costs are lower compared to SmF. The low water volume in SSF has also a large impact on the economy of the process mainly due to smaller fermenter-size, reduced downstream processing, reduced stirring and lower sterilization costs (Hölker and Lenz, 2005; Nigam, 2009; Pandey, 2003; Raghavarao et al., 2003). The main drawback of this type of cultivation concerns the scaling-up of the process, largely due to heat transfer and culture homogeneity problems (Di Luccio et al., 2004; Mitchell et al., 2000). However, research attention has been directed towards the development of bioreactors that overcome these difficulties.

Although many bioactive compounds are still produced by $\mathrm{SmF}$, in the last decades, there has been an increasing trend towards the utilization of the SSF technique to produce these compounds since this process has been shown more efficient than SmF (Nigam, 2009). 
Table 1

Examples of secondary metabolites produced with higher yield by solid-state fermentation than by submerged fermentation (Hölker et al., 2004).

\begin{tabular}{ll}
\hline Product & Microorganism \\
\hline 6-pentyl-alpha-pyrone & Trichoderma harzianum \\
Bafilomycin B1 + C1 & Streptomyces halstedii K122 \\
Benzoic acid & Bjerkandera adusta \\
Benzyl alcohol & Bjerkandera adusta \\
Cephamycin C & Streptomyces clavuligerus \\
Coconut aroma & Trichoderma sp. \\
Ergot alkaloids & Claviceps fusiformis \\
Giberellic acid & Giberella fujikuroi \\
Iturin & Bacillus subtillis \\
Ochratoxin & Aspergillus ochraceus \\
Oxytetracycline & Streptomyces rimossus \\
Penicillin & Penicillium chrysogenum \\
Rifamycin-B & Amycolatopsis mediterranei \\
Tetracycline & Streptomyces viridifaciens \\
\hline
\end{tabular}

Table 1 shows several examples of bioactive secondary metabolites that demonstrated significantly higher yields obtained by SSF than by SmF. Besides the higher yields, SSF has also been reported as a technique able to produce secondary metabolites in shorter times than SmF, without the need of aseptic conditions, and with capital costs significantly lesser.

Several important factors must be considered for the development of a successful bioprocess under SSF conditions. Some of the most important include the selection of a suitable microorganism strain and the solid support to be used. A variety of microorganisms, including fungi, yeasts and bacteria may be used in SSF processes; however, due to the low moisture content in the fermentation media, fungi and yeasts are the most commonly used microorganisms due to their ability to growth in environments with this characteristic. However, the choice of the microorganism to be used in SSF depends on the desired end product. Filamentous fungi have great potential to produce bioactive compounds by SSF, and therefore, they are the most commonly used microorganisms for this purpose (Aguilar et al., 2008; Nigam, 2009; Topakas et al., 2003a). Filamentous fungi have also received great attention due to their ability in producing thermostable enzymes of high scientific and commercial value, such as amylases, pectinases, xylanases, cellulases, chitinases, proteases, lipases, $\beta$-galactosidases, and others (Christakopoulos et al., 1990; Martins et al., 2002).

The right selection of the solid substrate is also of great importance for an efficient and economical production of the compound of interest. Mostly the production yields of secondary metabolites can be improved with a suitable choice of substrate or mixture of substrates with appropriate nutrients (Nigam, 2009). As a whole, the support material must present characteristic favorable for the microorganism development and be of low cost. These characteristics are easily found in many residual natural materials proceeding from agricultural and agroindustrial activities. In addition, the use of these residues as carbon sources through SSF provides an important way to reduce the fermentation cost and avoid environmental problems caused by their disposal, being an economical and interesting solution for countries with abundance of these materials. Several of these residues, including coffee pulp and husk, sugarcane and agave bagasses, fruit pulps and peels, corn cobs, among others, have been used as supports and/or substrates for the production of valuable compounds by SSF, such as enzymes (Guimarães et al., 2009; Mamma et al., 2008; Oliveira et al., 2006; Sabu et al., 2005), organic acids (John et al., 2006; Sharma et al., 2008; Vandenberghe et al., 2000), antibiotics (Adinarayana et al., 2003; Ellaiah et al., 2004), flavor and aroma compounds (Medeiros et al., 2006; Rossi et al., 2009; Sarhy-Bagnon et al., 2000), and bioactive compounds (Hernández et al., 2008; Vattem and Shetty, 2003). Table 2 summarizes some of the most recent studies in SSF, the microorganisms and solid supports employed. Note that a large variety of solid supports have been used in these processes, and fungi are the most used microorganisms.

The process variables including pretreatment and particle-size of substrates, medium ingredients, supplementation of growth medium, sterilization of SSF medium, moisture content, water activity $\left(a_{w}\right)$, inoculum density, temperature, $\mathrm{pH}$, agitation and aeration, have a significant effect on the efficiency of SSF processes (Nigam and Pandey, 2009). Among these, the moisture content and $a_{w}$ have an important role in SSF, and have been studied, described, and revised by several authors. Generally, the substrates have a water content oscillating between 30 and $85 \%$. Lower values may induce the sporulation of the microorganism, while more elevated levels may reduce the porosity of the system, which can produce oxygen transfer limitation, and increase

Table 2

Recent studies of solid-state fermentation using different microorganisms and solid supports.

\begin{tabular}{|c|c|c|}
\hline Microorganism & Solid support & Reference \\
\hline \multicolumn{3}{|l|}{ Fungi } \\
\hline Aspergillus niger & $\begin{array}{l}\text { Creosote bush leaves, variegated Caribbean agave, lemon peel, } \\
\text { orange peel, apple pomace, pistachio shell, wheat bran, coconut husk, } \\
\text { pecan nutshell, bean residues }\end{array}$ & Orzua et al., 2009 \\
\hline Aspergillus niveus & Sugarcane bagasse & Guimarães et al., 2009 \\
\hline Aspergillus oryzae & Red gram plant waste & Shankar and Mulimani, 2007 \\
\hline Aspergillus sojae & Crushed maize, maize meal, corncob & Ustok et al., 2007 \\
\hline $\begin{array}{l}\text { Bjerkandera adusta; Ganoderma applanatum; Phlebia rufa } \\
\text { Trametes versicolor }\end{array}$ & Wheat straw & Dinis et al., 2009 \\
\hline Phanerochaete chrysosporium & Rice straw & Yu et al., 2009 \\
\hline Penicillium sp. & Soybean bran & Wolski et al., 2009 \\
\hline Rhizopus chinensis & Combination of wheat bran and wheat flour & Sun et al., 2009 \\
\hline Sporotrichum thermophile & sesame oil cake & Singh and Satyanarayana, 2008a \\
\hline Trichosporon fermentans & Rice straw & Huang et al., 2009 \\
\hline \multicolumn{3}{|l|}{ Yeasts } \\
\hline Baker yeast AF37X & Sweet sorghum & Yu et al., 2008 \\
\hline \multirow[t]{2}{*}{ Saccharomyces cerevisiae } & Mahula flowers & Mohanty et al., 2009 \\
\hline & Corn stover & Zhao and Xia, 2009 \\
\hline \multicolumn{3}{|l|}{ Bacteria } \\
\hline Nocardia lactamdurans & Wheat bran, rice, soybean oil cake, soybean flour & Kagliwal et al., 2009 \\
\hline Bacillus sphaericus & Wheat bran & El-Bendary et al., 2008 \\
\hline Bacillus subtilis & Wheat bran & Gupta et al., 2008 \\
\hline Pseudomonas aeruginosa & Jatropha curcas seed cake & Mahanta et al., 2008 \\
\hline Streptomyces sp. & Coffee pulp & Orozco et al., 2008 \\
\hline
\end{tabular}


the risk of bacterial contamination (Pérez-Guerra et al., 2003). According to Raimbault (1998), the water requirements of microorganism may be better defined in terms of $a_{w}$ rather than water content in the solid substrate. The $a_{w}$ can be defined as the relationship between the vapor pressure of water in a system, and the vapor pressure of the pure water. In other words, $a_{w}$ indicates the available or accessible water for the growth of the microorganism, and affects the biomass development, metabolic reactions, and the mass transfer processes (Bellon-Maurel et al., 2003; Gervais and Molin, 2003).

The establishment of the most suitable conditions for use of the process variables is of relevance to achieve elevated process yields. The use of experimental design statistical methodology may be a useful tool to define such conditions performing a minimal number of experiments. Recently, several works report the use of statistical analysis to maximize the product formation through the establishment of the best SSF operational conditions. Such works include the production of enzymes such as $\alpha$-amylase (Reddy et al., 2003), inulinase (Xiong et al., 2007), phytase (Singh and Satyanarayana, 2008b), protease (Reddy et al., 2008), xylanase (Senthilkumar et al., 2005), and laccase (Liu et al., 2009), biosurfactants (Mukherjee et al., 2008) and organic acids such as citric acid (Imandi et al., 2008).

Finally, the selection of the most appropriate downstream process for the obtained product is also crucial when SSF processes are performed. The product obtained by SSF may be recovered from the solid fermented mass by extraction with solvents (aqueous or other solvents mixtures). The type of solvent and its concentration, as well as the ratio of solvent to the solid and $\mathrm{pH}$ are important variables that influence in the product extraction. In addition, since the metabolites diffuse throughout the solid mass during the culturing, long extraction-times may be required for complete product recovery. The cost of purification depends on the quality of the obtained extract. For example, the presence and concentration of inert compounds in the extract increase the cost of purification and therefore the cost of recovery is increased. Particularly those secondary metabolites which are used in bulk in the pharmaceutical and health industry and whose purity is governed by stringent regulations need to go through specific purification strategy (Nigam, 2009).

\section{Uses of SSF for bioactive phenolic compounds production}

\subsection{Phenolic content increase in food products}

Food quality is not only a function of nutritional values but also of the presence of bioactive compounds exerting positive effects on human health (Cassano et al., 2008). Phenolic compounds, also referred as polyphenols, are considered to be natural antioxidants and represent an important group of bioactive compounds in foods (Dueñas et al., 2005). These compounds are present in all plant foods but their type and levels vary enormously depending on the plant, genetic factors and environmental conditions (Kris-Etherton et al., 2002).

In the last years, SSF has been employed to increase the content of phenolic compounds in certain food products, thus enhancing their antioxidant activity. For example, black beans are well known for their high nutritional value containing isoflavones, vitamin E, saponins, carotenoids and anthocyanins (Choung et al., 2001). In a recent study on the bioprocessing of these beans to prepare koji using SSF with different food-grade filamentous fungi (in particular Aspergillus sp. and Rhizopus sp.), an enhancement of the antioxidant properties of the beans was observed, which might be related to the increase of phenol and anthocyanin contents (Lee et al., 2008). Nevertheless, the enhancement of the antioxidant activity of the black bean koji varied to each microorganism used. Similarly, SSF of grass peas cooked seeds using Rhizopus oligosporus caused an increase in the phenolic compounds content which significantly improved the antiradical properties of the seeds (Starzynska-Janiszewska et al., 2008).
Two different filamentous fungi (Aspergillus oryzae and Aspergillus awamori) used in SSF were very effective for the improvement of phenolic content and antioxidant properties of wheat grains. In this study, fermented wheat grains were considered to be antioxidant richer and healthier food supplement compared to non-fermented wheat grains (Bhanja et al., 2009). Soybean products fermented by SSF with Trichoderma harzianum showed stronger antioxidant activity than unfermented products, which was probably related to the markedly higher contents of phenolic acids, flavonoids and aglycone isoflavone with more free hydroxyl groups achieved during SSF (Singh et al., 2010). Chemical composition and bioactivity of stale rice were also improved by SSF with Cordyceps sinensis (Zhang et al., 2008).

Besides to increase the antioxidant activity of certain foods, bioconversion of phenolic compounds by SSF may also promote other alterations in the food properties, with influence on human health. An example of this is the SSF of mung beans (also known as green beans) with Rhizopus oligosporus. This process has been demonstrated as being able to mobilize the conjugate forms of phenolic precursors naturally found in mung beans and improves their health-linked functionality. According to Randhir and Shetty (2007), SSF of mung beans significantly increased the phenolic content enhancing the antioxidant activity of the beans. This antioxidant activity enhancement contributed to the $\alpha$-amylase inhibition (which is relevant for the diabetes controlling), as well as for the inhibition of the Helicobacter pylori growth (linked to peptic ulcer management).

\subsection{Production and extraction of bioactive phenolic compounds from agro-industrial residues}

Another valuable application of SSF is for the production or extraction of bioactive phenolic compounds from agro-industrial residues. Large amounts of these materials, including seeds, peels, husks, whole pomace, among others, are generated every year in the form of wastes, and are poorly valorized or left to decay on the land. Recently, increased attention has been given to these materials as abundantly available and cheap renewable feedstocks for the production of value-added compounds. In this sense, a number of them have been used as solid substrates in SSF processes for the production of different bioactive phenolic compounds (Hernández et al., 2008; Robledo et al., 2008; Vattem and Shetty, 2003; Zheng and Shetty, 2000).

Pomegranate wastes, for example, contain a significant amount of phenolic compounds, including anthocyanins (derived from delphinidin, cyanidin and pelargonidin), hydrolysable tannins (catechin, epicatechin, punicalin, pedunculagin, punicalagin, gallic and ellagic acid esters of glucose) (Cuccioloni et al., 2009; Gil et al., 2000), and several lignans (isolariciresinol, medioresinol, matairesinol, pinoresinol, syringaresinol, and secoisolariciresinol) (Bonzanini et al., 2009) can be mentioned. These phenolic compounds confer antioxidant, anti-mutagenic, anti-inflammatory and anticancer activities to the pomegranate wastes (Gil et al., 2000; Naveena et al., 2008; Negi et al., 2003). In recent studies, pomegranate husks were successfully used as support and nutrient sources for ellagic acid production by SSF with Aspergillus niger GH1 (Aguilar et al., 2008; Hernández et al., 2008). This process is economically interesting since from each ton of waste, it is possible to produce $8 \mathrm{~kg}$ of ellagic acid by SSF (Robledo et al., 2008). This process is also quite profitable from an industrial point of view, considering the commercial price of this acid and the low cost and abundance of the husks.

Cranberry pomace, the by-product of the cranberry juice processing industry, has also been pointed out as a good source of ellagic acid and other phenolic compounds (Vattem and Shetty, 2003; Zheng and Shetty, 1998, 2000). Bioprocessing of this waste by SSF with Lentinus edodes was useful to increase the ellagic acid content, being also an interesting alternative for the production of bioactive compounds 
(Vattem and Shetty, 2003). In India, Teri pod (Caesalpinia digyna) cover, the solid residue obtained during processing of the pod for recovery of oil, is a readily available agro-industrial by-product. This material contains tannin that can be used as substrate for microbial conversion to gallic acid. Bioconversion of tannin to gallic acid from the powder of Teri pod cover was successfully performed by SSF with the fungus Rhizopus oryzae (Kar et al., 1999).

Green coconut husk, an abundant agro-industrial residue in Brazil, is a potential source of ferulic acid, from which vanillin can be obtained via microbial conversion. In a recent study, the cultivation of the basidiomycete Phanerochaete chrysosporium under SSF in this residue caused the production of lignolytic enzymes that released ferulic acid from the coconut husk cell wall and subsequently, vanillin was obtained with high yield by the ferulic acid conversion (Barbosa et al., 2008). In fact, the action of enzymes such as $\alpha$-amylase, laccase and $\beta$-glucosidase, tannin acyl hydrolase, ellagitanin acyl hydrolase, among others, plays an important role in the mobilization of bioactive phenolic compounds during SSF (Cho et al., 2009; Robledo et al., 2008; Zheng and Shetty, 2000). The enzymes responsible for the degradation of lignocellulosic residues are mainly produced by fungi, since these microorganisms have two extracellular enzymatic systems: a hydrolytic system that produces hydrolases able to degrade polysaccharides, and an oxidative ligninolytic system, which degrades lignin and opens phenyl rings, increasing the free phenolic content (Sánchez, 2009). Table 3 summarizes some enzymes produced during SSF by lignocellulolytic fungi in several agro-industrial residues.

The enzyme $\beta$-glucosidase ( $\beta$-D-glucoside glucohydrolase) catalyzes the hydrolysis of glycosidic linkages in alkyl and aryl $\beta$-D-glucosides, as well as glycosides containing only carbohydrate residues (Vattem and Shetty, 2003). This enzyme has been described as being able to hydrolyze phenolic glycosides to release free phenolic acids. Some studies have suggested that crude Lentinus edodes $\beta$-glycosidase has higher capacity to release free phenolic acids from cranberry pomace than the commercial $\beta$-glycosidase (Vattem and Shetty, 2003; Zheng and Shetty, 2000). Such capacity was related to the possible presence of other enzymes such as esterases, in the crude $\beta$-glycosidase solution. These enzymes might help the cleavage of inter-sugar linkages, releasing the corresponding glycosides that were hydrolyzed liberating phenolic aglycon moieties.

During SSF of soybean with Bacillus pumilus HY1, Cho et al. (2009) reported a significant increase in the contents of flavanols and gallic acid, and a decrease in the amounts of isoflavone glycosides, malonylglycosides and flavanol gallates. This phenomenon was associated with bacterial $\beta$-glucosidase and esterase activities. Similarly, the improvement in the antioxidant potential of fermented rice has been associated with phenolic compound increases by $\beta$-glucosidase and $\alpha$-amylase activities during SSF (Bhanja et al., 2008). Recently, elagitannin acyl hydrolase has been related with the bioconversion of elagitannin into ellagic acid during SSF of pomegranate husks (Robledo et al., 2008).

Agricultural or forestry refuses including cereal and vegetable wastes such as straw, bagasse, stover, cobs, husks, among others, are lignocellulosic materials composed mainly of cellulose, hemicellulose and lignin. The lignin fraction in these materials contains numerous phenolic components, mainly acids such as ferulic, p-coumaric, syringic, vanillic and p-hydroxybenzoic (Mussatto et al., 2007), which can be recovered by SSF. Filamentous fungi like the white-rot fungi Phanerochaete chrysosporium, Trametes versicolor, Trametes hirsuta and Bjerkandera adusta have ability to degrade lignin since they produce a large range of enzymes necessary to break down this structure. As fungi grow on these agro-industrial residues, they utilize the polysaccharides after lignin degradation in order to grow and reproduce. This has the effect of increasing the nutritional value of the agro-industrial substrates that are generally low. After SSF the materials can be used as an animal feed or soil fertilizer (Nigam et al. 2009). The main extracellular enzymes participating in lignin degradation are lignin peroxidase (LiP), manganese peroxidase (MnP) and laccase (Philippoussis, 2009).

\subsection{Production and extraction of bioactive phenolic compounds from plants}

Plants produce a wide variety of bioactive compounds with significant applications in the health and food areas (Sarikaya and Ladisch, 1999; Ventura et al., 2008). Such compounds include a variety of flavonoids, phenolic acids, lignans, sallicylates, stanols, sterols, glucosinolates, among others (Hooper and Cassidy, 2006). In fact, plants are considered to be excellent sources of phenolic compounds with very interesting nutritional and therapeutic applications (Li et al., 2008; Trouillas et al., 2003). Among these compounds, a strong correlation between antioxidant activity and the total phenolic content in the plants has been observed, suggesting that phenolic compounds could be the major contributor of their antioxidant capacity (Li et al., 2008).

Phenolic compounds are widely distributed in plants, usually being found in higher concentrations in leaves and green steams (Bennett and Wallsgrove, 1994; Hyder et al., 2002). These compounds are considered natural defense substances, and their concentration in each plant may be influenced by several factors including physiological variations, environmental conditions, geographic variation, genetic factors and evolution (Figueiredo et al., 2008). The large

Table 3

Enzymes produced during solid-state fermentation by lignocellulolytic fungi in several agro-industrial residues.

\begin{tabular}{|c|c|c|c|}
\hline Enzyme (s) & Substrate & Microorganism & Reference \\
\hline \multirow[t]{3}{*}{$\beta$-glycosidase } & Lentinus edodes & Cranberry pomace & Zheng and Shetty, 2000 \\
\hline & Rhizopus oligosporus & Flour-spplemented guava waste & Correia et al., 2004 \\
\hline & Aspergillus oryzae & Rice & Bhanja et al., 2008 \\
\hline$\alpha$-amilase & Aspergillus oryzae & Rice & Bhanja et al., 2008 \\
\hline Polygalacturonase & Aspergillus niger & Wheat and soy brans & Castilho et al., 2000 \\
\hline \multirow[t]{2}{*}{ Xylanase } & Aspergillus niger & Apple pomace and cotton seed powder & Liu et al., 2008 \\
\hline & Sporotrichum thermophile & Corn cobs & Topakas et al., 2003b \\
\hline Cellulase & Aspergillus niger & Bran and cotton seed powder & Wang et al., 2006 \\
\hline \multicolumn{4}{|l|}{ Hemicellulase } \\
\hline \multicolumn{4}{|l|}{ Glucoamylase } \\
\hline \multicolumn{4}{|l|}{ Pectinase } \\
\hline \multicolumn{4}{|l|}{ Acidic proteinase } \\
\hline \multirow[t]{5}{*}{ Laccase } & Lentinus edodes & Corn & D'Annibale et al., 1996 \\
\hline & Pleurotus pulmonarius & Wheat bran and wheat straw & Marques de Souza et al., 2002 \\
\hline & & Wheat straw & Lang et al., 1996 \\
\hline & Pleurotus sp. & Wheat straw & Baldrian and Gabriel, 2002 \\
\hline & Pleurotus ostreatus & & \\
\hline Glycosidase & Aspergillus niger & Grape & Huerta-Ochoa et al., 2003 \\
\hline
\end{tabular}


biodiversity of plants existent, provides a great exploration field for researches on bioactive phenolic compounds and their biological properties (Shetty and McCue, 2003; Skerget et al., 2005; Tellez et al., 2001; Yesil-Celiktas et al., 2009).

Mexico is one of the world's richest countries in plant biodiversity, with a variety estimated between 22,000 and 30,000 species (Villaseñor, 2003; Villaseñor et al., 2007). The scientific and most common names of some plants that have been studied in SSF processes include Larrea tridentata (gobernadora or creosote bush), Flourensia cernua (hojasén or tarbush), Jatropha dioica (sangre de drago or dragon's blood), Euphorbia antisyphylitica (candelilla) and Turnera diffusa (damiana). These plants dominate some semiarid areas of northern Mexico and southwestern United States, as well as some desert regions of Argentina (Rzedowski and Huerta, 1994). Extracts from Larrea tridentata using organic solvents have shown great potential regarding biological properties, namely, antioxidant and antifungal activities (Abou-Gazar et al., 2004; Vargas-Arispuro et al., 2005). These biological properties were related to the presence of certain lignans, which are phenolic compounds characterized by having a diphenolic ring containing a 2,3-dibenzylbutane structure formed from the oxidative dimerization of two cinnamic acid residues. Larrea tridentata has also been used as a source of a valuable lignan named nordihydroguaiaretic acid (Hyder et al., 2002), known for its biological properties including anticancer and antiviral activities (Cui et al., 2008; Hwu et al., 2008; Vargas-Arispuro et al., 2005). It has been demonstrated in a recent study that Larrea tridentata was a potential source for gallic acid and tannase production by SSF using Aspergillus niger Aa-20 (Treviño-Cueto et al., 2007). High concentrations of gallic and ellagic acids were also obtained by Aspergillus niger PSH during SSF of tannin-rich aqueous extracts from Larrea tridentata impregnated in polyurethane foam (Ventura et al., 2008). Aspergillus niger GH1 has also been reported as being a fungi with great ability to hydrolyze ellagitannins into ellagic acid during SSF using Larrea tridentata as substrate (Aguilera-Carbo et al., 2009).

\section{Concluding remarks and future perspective}

SSF is a clean technology with great potential for application on the production or extraction of biologically active compounds from natural sources. The agro-industrial residues reuse in this area is of particular interest due to their availability, low cost, and characteristics that allow obtaining different bioactive phenolic compounds, besides being an environment friendly alternative for their disposal. Another interesting application for SSF is to increase the bioactive phenolic compounds content in food products. This area has great potential to expand in a near future due to the increased consumer desire to improve health through food.

\section{Acknowledgments}

We acknowledge the financial support of Science and Technology Foundation of Portugal through grants SFRH/BD/40439/2007 and SFRH/BPD/38212/2007, and Mexican Council of Science and Technology through program SEP-CONACYT-24348/2007-2010.

\section{References}

Abou-Gazar H, Bedir E, Takamatsu S, Ferreira D, Khan IA. Antioxidant lignans from Larrea tridentata. Phytochemistry 2004;65:2499-505.

Adinarayana K, Prabhakar T, Srinivasulu V, Anitha Rao M, Jhansi Lakshmi P, Ellaiah P. Optimization of process parameters for cephalosporin $C$ production under solid state fermentation from Acremonium chrysogenum. Process Biochem 2003;39: 171-7.

Aguilar CN, Aguilera-Carbo A, Robledo A, Ventura J, Belmares R, Martinez D, et al. Production of antioxidants nutraceuticals by solid-state cultures of pomegranate (Punica granatum) peel and creosote bush (Larrea tridentata) leaves. Food Technol Biotechnol 2008;46:218-22.
Aguilera-Carbo A, Hernández JS, Augur C, Prado-Barragan LA, Favela-Torres E, Aguilar $\mathrm{CN}$. Ellagic acid production from biodegradation of creosote bush ellagitannins by Aspergillus niger in solid state sulture. Food Bioprocess Technol 2009;2:208-12.

Balasundram N, Sundram K, Samman S. Phenolic compounds in plants and agriindustrial by-products: antioxidant activity, occurrence, and potential uses. Food Chem 2006;99:191-203.

Baldrian P, Gabriel J. Variability of laccase activity in the white-rot basidiomycete Pleurotus ostreatus. Folia Microbiol 2002;47:385-90.

Barbosa ES, Perrone D, Vendramini ALA, Leite SGF. Vanillin production by Phanerochaete chrysosporium grown on green coconut agro-industrial husk in solid state fermentation. Bioresources 2008;3:1042-50.

Barrios-González J, Fernández FJ, Tomasini A, Mejía A. Secondary metabolites production by solid-state fermentation. Malays J Microbiol 2005;1:1-6.

Bellon-Maurel V, Orliac O, Christen P. Sensors and measurements in solid state fermentation: a review. Process Biochem 2003:38:881-96.

Bennett RN, Wallsgrove RM. Secondary metabolism in plant defence mechanisms. New Phytol 1994;127:617-33.

Bhanja T, Rout S, Banerjee R, Bhattacharyya BC. Studies on the performance of a new bioreactor for improving antioxidant potential of rice. Lebensm Wiss Technol 2008;41:1459-65.

Bhanja T, Kumari A, Banerjee R. Enrichment of phenolics and free radical scavenging property of wheat koji prepared with two filamentous fungi. Bioresour Technol 2009;100:2861-6.

Bonzanini F, Bruni R, Palla G, Serlataite N, Caligiani A. Identification and distribution of lignans in Punica granatum L. fruit endocarp, pulp, seeds, wood knots and commercial juices by GC-MS. Food Chem 2009;117:745-9.

Bravo L. Polyphenols: chemistry, dietary sources, metabolism, and nutritional significance. Nutr Rev 1998;56:317-33.

Cassano A. Donato L, Conidi C, Drioli E. Recovery of bioactive compounds in kiwifruit juice by ultrafiltration. Innov Food Sci Emerg 2008;9:556-62.

Castilho LR, Medronho RA, Alves TLM. Production and extraction of pectinases obtained by solid state fermentation of agroindustrial residues with Aspergillus niger. Bioresour Technol 2000;71:45-50.

Cho KM, Hong SY, Math RK, Lee JH, Kambiranda DM, Kim JM, et al. Biotransformation of phenolics (isoflavones, flavanols and phenolic acids) during the fermentation of cheonggukjang by Bacillus pumilus HY1. Food Chem 2009;114:413-9.

Choung M-G, Baek I-Y, Kang S-T, Han W-Y, Shin D-C, Moon H-P, et al. Isolation and determination of anthocyanins in seed coats of black soybean (Glycine max (L.) Merr.). J Agr Food Chem 2001;49:5848-51.

Christakopoulos P, Macris BJ, Kekos D. Exceptionally thermostable a- and $\beta$ galactosidases from Aspergillus niger separated in one step. Process Biochem Int 1990;25:210-2.

Conforti F, Menichini F, Formisano C, Rigano D, Senatore F, Arnold NA, et al. Comparative chemical composition, free radical-scavenging and cytotoxic properties of essential oils of six Stachys species from different regions of the Mediterranean Area. Food Chem 2009;116:898-905.

Correia RTP, McCue P, Magalhães MMA, Macedo GR, Shetty K. Phenolic antioxidant enrichment of soy flour-supplemented guava waste by Rhizopus oligosporus mediated solid-state bioprocessing. J Food Biochem 2004;28:404-18.

Cortazar E, Bartolomé L, Delgado A, Etxebarria N, Fernández LA, Usobiaga A, et al. Optimisation of microwave-assisted extraction for the determination of nonylphenols and phthalate esters in sediment samples and comparison with pressurised solvent extraction. Anal Chim Acta 2005;534:247-54.

Cuccioloni M, Mozzicafreddo M, Sparapani L, Spina M, Eleuteri AM, Fioretti E, et al. Pomegranate fruit components modulate human thrombin. Fitoterapia 2009;80: 301-5.

Cui Y, Lu C, Liu L, Sun D, Yao N, Tan S, et al. Reactivation of methylation-silenced tumor suppressor gene p161NK4a by nordihydroguaiaretic acid and its implication in G1 cell cycle arrest. Life Sci 2008;82:247-55.

D'Annibale A, Celletti D, Felici M, Di Mattia E, Giovannozzi-Sermani G. Substrate specificity of laccase from Lentinus edodes. Acta Biotechnol 1996;16:257-70.

Di Luccio M, Capra F, Ribeiro NP, Vargas GDLP, Freire DMG, Oliveira D. Effect of temperature, moisture, and carbon supplementation on lipase production by solidstate fermentation of soy cake by Penicillium simplicissimum. Appl Biochem Biotechnol 2004;113:173-80.

Dinis MJ, Bezerra RMF, Nunes F, Dias AA, Guedes CV, Ferreira LMM, et al. Modification of wheat straw lignin by solid state fermentation with white-rot fungi. Bioresour Technol 2009;100:4829-35.

Dueñas M, Fernández D, Hernández T, Estrella I, Muñoz R. Bioactive phenolic compounds of cowpeas (Vigna sinensis L.). Modifications by fermentation with natural microflora and with Lactobacillus plantarum ATCC 14917. J Sci Food Agr 2005;85:297-304.

El-Bendary MA, Monoram D, Foda MS. Efficient mosquitocidal toxin production by Bacillus sphaericus using cheese whey permeate under both submerged and solid state fermentations. J Invertebr Pathol 2008;98:46-53.

Ellaiah P, Srinivasulu B, Adinarayana K. Optimisation studies on neomycin production by a mutant strain of Streptomyces marinensis in solid state fermentation. Process Biochem 2004;39:529-34.

Figueiredo AC, Barroso JG, Pedro LG, Scheffer JJC. Factors affecting secondary metabolite production in plants: volatile components and essential oils. Flavour Frag J 2008;23:213-26.

Gervais P, Molin P. The role of water in solid-state fermentation. Biochem Eng J 2003; 13:85-101.

Gil MI, Tomás-Barberán FA, Hess-Pierce B, Holcroft DM, Kader AA. Antioxidant activity of pomegranate juice and its relationship with phenolic composition and processing. J Agric Food Chem 2000;48:4581-9. 
Guimarães LHS, Somera AF, Terenzi HF, Polizeli MLTM, Jorge JA. Production of $\beta-$ fructofuranosidases by Aspergillus niveus using agroindustrial residues as carbon sources: Characterization of an intracellular enzyme accumulated in the presence of glucose. Process Biochem 2009;44:237-41.

Gupta S, Kapoor M, Sharma KK, Nair LM, Kuhad RC. Production and recovery of an alkaline exo-polygalacturonase from Bacillus subtilis RCK under solid-state fermentation using statistical approach. Bioresour Technol 2008;99:937-45.

Ham S-S, Kim S-H, Moon S-Y, Chung MJ, Cui C-B, Han E-K, et al. Antimutagenic effects of subfractions of Chaga mushroom (Inonotus obliquus) extract. Mutat Res Gen Toxicol En 2009;672:55-9.

Harborne JB, Baxter H, Moss GP. Phytochemical dictionary: handbook of bioactive compounds from plants. second ed. London: Taylor \& Francis; 1999.

Hernández JS, Aguilera-Carbó AF, Rodríguez Herrera R, Martínez JL, Aguilar CN. Kinetic production of the antioxidant ellagic acid by fungal solid state culture. Proceedings of the 10th international chemical and biological engineering conference. Portugal: CHEMPOR; 2008. p. 1849-54.

Hölker U, Lenz J. Solid-state fermentation: are there any biotechnological advantages? Curr Opin Microbiol 2005;8:301-6.

Hölker U, Höfer M, Lenz J. Biotechnological advances of laboratory-scale solid-state fermentation with fungi. Appl Microbiol Biotechnol 2004;64:175-86.

Hooper L, Cassidy A. A review of the health care potential of bioactive compounds. J Sci Food Agric 2006:86:1805-13.

Huang C, Zong M-H, Wu H, Liu Q-P. Microbial oil production from rice straw hydrolysate by Trichosporon fermentans. Bioresour Technol 2009;100:4535-8.

Huerta-Ochoa S, Nicolás-Santiago MS, Acosta-Hernández WD, Prado-Barragán LA, Gutiérrez-López GF, García-Almendárez BE, et al. Production and partial purification of glycosidases obtained by solid-state fermentation of grape pomace using Aspergillus niger 10. In: Gutiérrez-López GF, Barbosa-Cánovas GV, editors. Food science and food biotechnology. Washington: CRC Press LLC; 2003. p. 119-38.

Hwu JR, Hsu M-H, Huang RCC. New nordihydroguaiaretic acid derivatives as anti-HIV agents. Bioorg Med Chem Lett 2008;18:1884-8.

Hyder PW, Fredrickson EL, Estell RE, Tellez M, Gibbens RP. Distribution and concentration of total phenolics, condensed tannins, and nordihydroguaiaretic acid (NDGA) in creosotebush (Larrea tridentata). Biochem Syst Ecol 2002;30:905-12.

Imandi SB, Bandaru VVR, Somalanka SR, Bandaru SR, Garapati HR. Application of statistical experimental designs for the optimization of medium constituents for the production of citric acid from pineapple waste. Bioresour Technol 2008;99: 4445-50.

Jiménez JP, Serrano J, Tabernero M, Arranz S, Díaz-Rubio ME, García-Diz L, et al. Effects of grape antioxidant dietary fiber in cardiovascular disease risk factors. Nutrition 2008;24:646-53.

John RP, Nampoothiri KM, Pandey A. Solid-state fermentation for L-lactic acid production from agro wastes using Lactobacillus delbrueckii. Process Biochem 2006;41:759-63.

Kagliwal LD, Survase SA, Singhal RS. A novel medium for the production of cephamycin C by Nocardia lactamdurans using solid-state fermentation. Bioresour Technol 2009;100:2600-6.

Kar B, Banerjee R, Bhattacharyya BC. Microbial production of gallic acid by modified solid state fermentation. J Ind Microbiol Biotnol 1999;23:173-7.

Kim G-N, Shin J-G, Jang H-D. Antioxidant and antidiabetic activity of Dangyuja (Citrus grandis Osbeck) extract treated with Aspergillus saitoi. Food Chem 2009;117:35-41.

Kris-Etherton PM, Hecker KD, Bonanome A, Coval SM, Binkoski AE, Hilpert KF, et al. Bioactive compounds in foods: their role in the prevention of cardiovascular disease and cancer. Am J Med 2002:113:71S-88S.

Lang E, Nerud F, Novotná E, Zadrazil F, Martens R. Production of ligninolytic exoenzymes and ${ }^{14} \mathrm{C}$-pyrene mineralization by Pleurotus sp. in lignocellulose substrate. Folia Microbiol 1996;41:489-93.

Lee IH, Hung YH, Chou CC. Solid-state fermentation with fungi to enhance the antioxidative activity, total phenolic and anthocyanin contents of black bean. Int J Food Microbiol 2008;121:150-6.

Li H-B, Wong C-C, Cheng K-W, Chen F. Antioxidant properties in vitro and total phenolic contents in methanol extracts from medicinal plants. Lebensm Wiss Technol 2008;41:385-90.

Liu C, Sun Z-T, Du J-H, Wang J. Response surface optimization of fermentation conditions for producing xylanase by Aspergillus niger SL-05. J Ind Microbiol Biotechnol 2008;35:703-11.

Liu L, Lin Z, Zheng T, Lin L, Zheng C, Lin Z, et al. Fermentation optimization and characterization of the laccase from Pleurotus ostreatus strain 10969. Enzyme Microb Technol 2009;44:426-33.

Mahanta N, Gupta A, Khare SK. Production of protease and lipase by solvent tolerant Pseudomonas aeruginosa PseA in solid-state fermentation using Jatropha curcas seed cake as substrate. Bioresour Technol 2008;99:1729-35.

Mamma D, Kourtoglou E, Christakopoulos P. Fungal multienzyme production on industrial by-products of the citrus-processing industry. Bioresour Technol 2008;99:2373-83.

Markom M, Hasan M, Daud WRW, Singh H, Jahim JM. Extraction of hydrolysable tannins from Phyllanthus niruri Linn.: effects of solvents and extraction methods. Sep Purif Technol 2007:52:487-96.

Marques de Souza CG, Zilly A, Peralta RM. Production of laccase as the sole phenoloxidase by a Brazilian strain of Plerotus pulmonarius in solid state fermentation. J Basic Microbiol 2002;42:83-90.

Martins ES, Silva D, Da Silva R, Gomes E. Solid state production of thermostable pectinases from thermophilic Thermoascus aurantiacus. Process Biochem 2002;37:949-54.

Martins S, Aguilar CN, de la Garza-Rodriguez I, Mussatto SI, Teixeira JA. Kinetic study of nordihydroguaiaretic acid recovery from Larrea tridentata by microwave-assisted extraction. J Chem Technol Biotechnol 2010;85:1142-7.
Medeiros ABP, Pandey A, Vandenberghe LPS, Pastore GM, Soccol CR. Production and recovery of aroma compounds produced by solid-state fermentation using different adsorbents. Food Technol Biotechnol 2006;44:47-51.

Mitchell DA, Krieger N, Stuart DM, Pandey A. New developments in solid-state fermentation: II. Rational approaches to the design, operation and scale-up of bioreactors. Process Biochem 2000;35:1211-25.

Mohanty SK, Behera S, Swain MR, Ray RC. Bioethanol production from mahula (Madhuca latifolia L.) flowers by solid-state fermentation. Appl Energy 2009;86:640-4.

Mukherjee S, Das P, Sivapathasekaran C, Sen R. Enhanced production of biosurfactant by a marine bacterium on statistical screening of nutritional parameters. Biochem Eng J 2008;42:254-60.

Mussatto SI, Dragone G, Roberto IC. Ferulic and p-coumaric acids extraction by alkaline hydrolysis of brewer's spent grain. Ind Crop Prod 2007;25:231-7.

Naveena BM, Sen AR, Vaithiyanathan S, Babji Y, Kondaiah N. Comparative efficacy of pomegranate juice, pomegranate rind powder extract and BHT as antioxidants in cooked chicken patties. Meat Sci 2008;80:1304-8.

Negi PS, Jayaprakasha GK, Jena BS. Antioxidant and antimutagenic activities of pomegranate peel extracts. Food Chem 2003;80:393-7.

Nigam PS. Production of bioactive secondary metabolites. In: Nigam PS, Pandey A editors. Biotechnology for agro-industrial residues utilization. first ed. Netherlands: Springer; 2009. p. 129-45.

Nigam PS, Pandey A. Solid-state fermentation technology for bioconversion of biomass and agricultural residues. In: Nigam PS, Pandey A, editors. Biotechnology for agroindustrial residues utilization. first ed. Netherlands: Springer; 2009. p. 197-221.

Nigam PS, Gupta N, Anthwal A. Pre-treatment of agro-industrial residues. In: Nigam PS, Pandey A, editors. Biotechnology for agro-industrial residues utilization. first ed. Netherlands: Springer; 2009. p. 13-33.

Oliveira LA, Porto ALF, Tambourgi EB. Production of xylanase and protease by Penicillium janthinellum CRC 87M-115 from different agricultural wastes. Bioresour Technol 2006;97:862-7.

Orozco AL, Pérez MI, Guevara O, Rodríguez J, Hernández M, González-Vila FJ, et al Biotechnological enhancement of coffee pulp residues by solid-state fermentation with Streptomyces. Py-GC/MS analysis. J Anal Appl Pyrol 2008;81:247-52.

Orzua MC, Mussatto SI, Contreras-Esquivel JC, Rodriguez R, De la Garza H, Teixeira JA, et al. Exploitation of agro industrial wastes as immobilization carrier for solid-state fermentation. Ind Crop Prod 2009;30:24-7.

Pandey A. Solid state fermentation. Biochem Eng J 2003;13:81-4.

Parvathy KS, Negi PS, Srinivas P. Antioxidant, antimutagenic and antibacterial activities of curcumin- $\beta$-diglusoside. Food Chem 2009;115:265-71.

Pérez-Guerra N, Torrado-Agrasar A, López-Marias C, Pastrana L. Main characteristics and applications of solid substrate fermentation. Electron J Environ Agric Food Chem 2003;2:343-50.

Philippoussis AN. Production of mushrooms using agro-industrial residues as substrates. In: Nigam PS, Pandey A, editors. Biotechnology for agro-industrial residues utilization. first ed. Netherlands: Springer; 2009. p. 163-96.

Raghavarao KSMS, Ranganathan TV, Karanth NG. Some engineering aspects of solidstate fermentation. Biochem Eng J 2003;13:127-35.

Raimbault M. General and microbiological aspects of solid substrate fermentation. Electron J Biotechnol 1998;1:174-88.

Randhir R, Shetty K. Mung beans processed by solid-state bioconversion improves phenolic content and functionality relevant for diabetes and ulcer management. Innovations Food Sci Emerg Technol 2007;8:197-204.

Reddy PRM, Ramesh B, Mrudula S, Reddy G, Seenayya G. Production of thermostable B-amylase by Clostridium thermosulfurogenes SV2 in solid-state fermentation: Optimization of nutrient levels using response surface methodology. Process Biochem 2003;39:267-77.

Reddy LVA, Wee Y-J, Yun J-S, Ryu H-W. Optimization of alkaline protease production by batch culture of Bacillus sp. RKY3 through Plackett-Burman and response surface methodological approaches. Bioresour Technol 2008;99:2242-9.

Robledo A, Aguilera-Carbó A, Rodríguez R, Martinez JL, Garza Y, Aguilar CN. Ellagic acid production by Aspergillus niger in solid state fermentation of pomegranate residues. J Ind Microbiol Biotech 2008;35:507-13.

Rossi SC, Vandenberghe LPS, Pereira BMP, Gago FD, Rizzolo JA, Pandey A, et al Improving fruity aroma production by fungi in SSF using citric pulp. Food Res Int 2009;42:484-6.

Rzedowski J, Huerta M. Xerophilous health. In: Rzedowski J, editor. The Mexican vegetation. Mexico: Limusa; 1994. p. 237-61.

Sabu A, Pandey A, Jaafar Daud M, Szakacs G. Tamarind seed powder and palm kerne cake: two novel agro residues for the production of tannase under solid state fermentation by Aspergillus niger ATCC 16620. Bioresour Technol 2005;96:1223-8.

Sánchez C. Lignocellulosic residues: biodegradation and bioconversion by fungi. Biotechnol Adv 2009;27:185-94.

Sarhy-Bagnon V, Lozano P, Saucedo-Castañeda G, Roussos S. Production of 6-pentyl- $\alpha$ pyrone by Trichoderma harzianum in liquid and solid state cultures. Process Biochem 2000:36:103-9.

Sarikaya A, Ladisch MR. Solid-state fermentation of lignocellulosic plant residues from Brassica napus by Pleurotus ostreatus. Appl Biochem Biotechnol 1999;82:1-15.

Senthilkumar SR, Ashokkumar B, Raj KC, Gunasekaran P. Optimization of medium composition for alkali-stable xylanase production by Aspergillus fischeri Fxn 1 in solid-state fermentation using central composite rotary design. Bioresour Technol 2005;96:1380-6.

Shankar SK, Mulimani VH. $\alpha$-Galactosidade production by Aspergillus oryzae in solidstate fermentation. Bioresour Technol 2007;98:958-61.

Sharma A, Vivekanand V, Singh RP. Solid-state fermentation for gluconic acid production from sugarcane molasses by Aspergillus niger ARNU-4 employing tea waste as the novel solid support. Bioresour Technol 2008;99:3444-50. 
Shetty K, McCue P. Phenolic antioxidant biosynthesis in plants for functional food application: integration of systems biology and biotechnological approaches. Food Biotechnol 2003;17:67-97.

Singh B, Satyanarayana T. Phytase production by a thermophilic mould Sporotrichum thermophile in solid state fermentation and its potential applications. Bioresour Technol 2008a;99:2824-30.

Singh B, Satyanarayana T. Improved phytase production by a thermophilic mould Sporotrichum thermophile in submerged fermentation due to statistical optimization. Bioresour Technol 2008b;99:824-30.

Singh HB, Singh BN, Singh SP, Nautiyal CS. Solid-state cultivation of Trichoderma harzianum NBRI-1055 for modulating natural antioxidants in soybean seed matrix. Bioresour Technol 2010;101:6444-53.

Skerget M, Kotnik P, Hadolin M, Hras AR, Simonic M, Knez Z. Phenols, proanthocyanidins, flavones and flavonols in some plant materials and their antioxidant activities. Food Chem 2005;89:191-8.

Starzynska-Janiszewska A, Stodolak B, Jamróz M. Antioxidant properties of extracts from fermented and cooked seeds of Polish cultivars of Lathyrus sativus. Food Chem 2008;109:285-92.

Sun SY, Xu Y, Wang D. Novel minor lipase from Rhizopus chinensis during solid-state fermentation: Biochemical characterization and its esterification for ester synthesis. Bioresour Technol 2009;100:2607-12.

Tellez M, Estell R, Fredrickson E, Powell J, Wedge D, Schrader $K$, et al. Extracts of Flourensia cernua (L): volatile constituents and antifungal, antialgal, and antitermite bioactivities. J Chem Ecol 2001;27:2263-73.

Topakas E, Kalogeris E, Kekos D, Macris BJ, Christakopoulos P. Bioconversion of ferulic acid into vanillic acid by the thermophilic fungus Sporotrichum thermophile. Lebensm Wiss Technol 2003a;36:561-5.

Topakas E, Katapodis P, Kekos D, Macris BJ, Christakopoulos P. Production and partial characterization of xylanase by Sporotrichum thermophile under solid-state fermentation. World J Microbiol Biotechnol 2003b;19:195-8.

Treviño-Cueto B, Luos M, Contreras-Esquivel JC, Rodríguez R, Aguilera A, Aguilar CN. Gallic acid and tannase accumulation during fungal solid state culture of tanninrich desert plant (Larrea tridentata Cov.). Bioresour Technol 2007:98:721-4.

Trouillas P, Calliste C-A, Allais D-P, Simon A, Marfak A, Delage C, et al. Antioxidant, antiinflammatory and antiproliferative properties of sixteen water plant extracts used in the Limousin countryside as herbal teas. Food Chem 2003;80:399-407.

Ustok FI, Tari C, Gogus N. Solid-state production of polygalacturonase by Aspergillus sojae ATCC 20235. J Biotechnol 2007;127:322-34.

Vandenberghe LPS, Soccol CR, Pandey A, Lebeault J-M. Solid-state fermentation for the synthesis of citric acid by Aspergillus niger. Bioresour Technol 2000;74:175-8.

Vargas-Arispuro I, Reyes-Báez R, Rivera-Castañeda G, Martínez-Téllez MA, RiveroEspejel I. Antifungal lignans from the creosote bush (Larrea tridentata). Ind Crops Prod 2005;22:101-7.
Vattem DA, Shetty K. Ellagic acid production and phenolic antioxidant activity in cranberry pomace (Vaccinium macrocarpon) mediated by Lentinus edodes using a solid-state system. Process Biochem 2003;39:367-79.

Ventura J, Belmares R, Aguilera-Carbo A, Gutiérrez-Sanchez G, Rodríguez-Herrera R, Aguilar CN. Fungal biodegradation of tannins from Creosote Bush (Larrea tridentata) and Tar Bush (Fluorensia cernua) for gallic and ellagic acid production. Food Technol Biotechnol 2008;46:213-7.

Villaseñor JL, Maeda P, Rosell JA, Ortiz E. Plant families as predictors of plant biodiversity in Mexico. Div Distrib 2007;13:871-6.

Villaseñor JL. Diversidad y distribución de las magnoliophyta de México. Interciencia 2003;28:160-7.

Wang L, Weller CL. Recent advances in extraction of nutraceuticals from plants. Trends Food Sci Technol 2006;17:300-12.

Wang X-J, Bai J-G, Liang Y-X. Optimization of multienzyme production by two mixed strains in solid-state fermentation. Appl Microbiol Biotechnol 2006;73:533-40.

Wolski E, Menusi E, Remonatto D, Vardanega R, Arbter F, Rigo E, et al. Partial characterization of lipases produced by a newly isolated Penicillium $s p$. in solid state and submerged fermentation: a comparative study. Lebensm-Wiss. Technology 2009;42:1557-60.

Xiong C, Jinhua W, Dongsheng L. Optimization of solid-state medium for the production of inulinase by Kluyveromyces S120 using response surface methodology. Biochem Eng J 2007;34:179-84.

Yesil-Celiktas O, Ganzera M, Akgun I, Sevimli C, Korkmaz KS, Bedir E. Determination of polyphenolic constituents and biological activities of bark extracts from different Pinus species. J Sci Food Agric 2009;89:1339-45.

Yu J, Zhang X, Tan T. Ethanol production by solid state fermentation of sweet sorghum using thermotolerant yeast strain. Fuel Process Technol 2008;89:1056-9.

Yu M, Zeng G, Chen Y, Yu H, Huang D, Tang L. Influence of Phanerochaete chrysosporium on microbial communities and lignocellulose degradation during solid-state fermentation of rice straw. Process Biochem 2009;44:17-22.

Zhang Z, Lei Z, Lu Y, Lu Z, Chen Y. Chemical composition and bioactivity changes in stale rice after fermentation with Cordyceps sinensis. J Biosci Bioeng 2008;106:188-93.

Zhao J, Xia L. Simultaneous saccharification and fermentation of alkaline-pretreated corn stover to ethanol using a recombinant yeast strain. Fuel Process Technol 2009;99:1193-7.

Zheng Z, Shetty K. Solid-state bioconversion of phenolics from cranberry pomace and role of Lentinus edodes B-glucosidase. J Agric Food Chem 2000;48:895-900.

Zheng Z, Shetty K. Cranberry processing waste for solid-state fungal inoculant production. Process Biochem 1998;33:323-9. 